\title{
Correction to: Factor analysis to investigate genotype and genotype $\times$ environment interaction effects on pro- vitamin $A$ content and yield in maize synthetics
}

\author{
Wende Mengesha $(\mathbb{D} \cdot$ Abebe Menkir - Silvestro Meseka • Bunmi Bossey • \\ Agbona Afolabi · Juan Burgueno $\cdot$ Jose Crossa
}

Published online: 9 December 2019

(C) The Author(s) 2019

\section{Correction to: Euphytica (2019) 215:180 \\ https://doi.org/10.1007/s10681-019-2505-3}

The above mentioned article, was originally published electronically on the publisher's internet portal (currently SpringerLink) on 4 October 2019 without open access.

With the author(s)' decision to opt for Open Choice the copyright of the article changed on 10 December to (C) The Author(s) 2019 and the article is forthwith distributed under the terms of the Creative Commons Attribution 4.0 International License (http:// creativecommons.org/licenses/by/4.0/), which permits use, duplication, adaptation, distribution and reproduction in any medium or format, as long as you give appropriate credit to the original author(s) and the source, provide a link to the Creative Commons license and indicate if changes were made.

Open Access This article is distributed under the terms of the Creative Commons Attribution 4.0 International License (http:// creativecommons.org/licenses/by/4.0/), which permits unrestricted use, distribution, and reproduction in any medium, provided you give appropriate credit to the original author(s) and the source, provide a link to the Creative Commons license, and indicate if changes were made.

Publisher's Note Springer Nature remains neutral with regard to jurisdictional claims in published maps and institutional affiliations.
The original article can be found online at https:// doi.org/10.1007/s10681-019-2505-3.

W. Mengesha $(\bowtie) \cdot$ A. Menkir · S. Meseka ·

B. Bossey - A. Afolabi

International Institute of Tropical Agriculture (IITA), Oyo

Road, PMB 5320, Ibadan, Nigeria

e-mail: W.Mengesha@cgiar.org

J. Burgueno $\cdot$ J. Crossa

International Maize and Wheat Improvement Center (CIMMYT), Apdo. Postal 6-641, 06600 Mexico City,

Mexico 